\title{
The Development Trend of the Manufacturing Industry and the "One Belt And One Road" Model Research from the Historical Perspective
}

\author{
Danting Xiang* \\ School of Marxism, Zhe Jiang College, Shang Hai University of Finance and Economics, Jin Hua, Zhe \\ Jiang, China \\ *Corresponding Author.
}

\begin{abstract}
As the United States subprime mortgage crisis triggered by the global economic crisis, in the face of the plight of world economic recovery is weak, in order to seek better way out of this dilemma, this article emphatically from the world market on the history of the development of vertical comb, to conduct a comprehensive in-depth theory to the essence of the manufacturing industry movement rule and its development trend. Through the integrated use of literature research, exploratory study, information research methods and scientific thinking method, inductive deductive system science method, and analogical reasoning, abstract generalization analysis of a series of existing theory of manufacturing industry substance and on the basis of comprehensive study to clarify the essence of the manufacturing industry movement rule and its development trend. Therefore, against the background of sluggish world economic recovery, we must start a new engine of world economic development under the original engine of world economic development. "One Belt And One Road" reflects and complies with the historical trend of economic globalization.
\end{abstract}

Keywords: "The Silk Road", "One Belt And One Road", World market, Economic globalization, Manufacturing industry

\section{Introduction}

Throughout human history, it is not difficult to find that the communication among human beings almost runs through the development of human history. Just as Marx stressed in the Theses on Feuerbach that "the essence of human is not the abstract inherent in a single individual, in its reality, it is the sum of all social relations". [1] This means that man, in essence, confirms his essence through the social relations formed in his social interactions. Therefore, it can be said that social interaction is the basis and basis for the development and continuation of human society. Without social interaction, there would be no existence and development of human society. The most fundamental form of communication in the historical development of human social communication is the economic communication with commodities as the media.

\section{The Foundation of Research}

From ancient people of countries along the silk road first with people around in small range between barter for medium and form of communication, to gradually developed as the universal equivalent as a medium of communication, to the currency as the medium of communication, from a certain region within the small range of domestic Commodity Exchange gradually expanding, along with the expansion of the sphere, the increasing of Commodity Exchange, and gradually from the domestic market spread to neighboring countries constantly, thus forming the across Asia and Europe as the main body of the three continents commodity trade exchanges network and gradually spread to the world, Thus lays an important foundation for the formation and development of economic globalization. Therefore, from the formation of the world market dominated by the West to today's economic globalization, Asia, Europe and Africa have always been the main components of the world market, which is built on the basis of the commodity trade network formed by the ancient Silk Road. At the same time, accompanied by long dominated by western economic globalization today, the pattern of the economic globalization actually faced

ISSN: 0010-8189

(C) CONVERTER 2020

www.converter-magazine.info 
with new adjustment and transformation, namely into "after the era of globalization", "after the era of globalization" is not a negative for the development of economic globalization trend, in fact is the optimization of the era of economic globalization, "after the era of globalization" is in order to better resolve and deal with the current dominated by the west under the pattern of economic globalization, the emergence of a series of problems and obstacles, affecting the development of the global economy by adjusting the upgrade, to remove obstacles and barriers of global economic development, Thus, it provides a more healthy and sustainable driving force for global economic development. In this context, it gives birth to and boosts the formation and development of "One Belt And One Road".

2.1 The historical source of the formation and development of the world market from "The Silk Road" to "One Belt And One Road"

In 2008 the us subprime mortgage crisis triggered by the global economic crisis, the global economy, especially the weak economic recovery in the west, so in the western countries dominated by western economic globalization under the system of the co-action, a growing number of western countries from mainly aimed at the international market, to turn on the domestic market and its own economic recovery and development, so countries of trade protectionism, by raising tariffs and import restrictions, to trying to protect their national industries and the development of the real economy. For the vast number of developing countries, is undoubtedly a fatal blow to the traditional dominated by western countries in the world market in the developing countries at a disadvantage, but with the economic globalization under the condition of global trade to a certain extent, promote the development of its economy to a certain extent, however, the current world trade, make the development of the vast developing countries lost an important source of economic and trade, so the needs of developing countries seeking to facing a new development in order to better solve the crisis and hidden dangers. Developing countries in the development of the overall strength, only by their own strength is difficult to be out of the woods now facing the global economy and the crisis, it must through the solidarity and cooperation with other countries to jointly cope with the ongoing global crisis, unity and cooperation, of course, the object is first and foremost with the neighboring countries, followed by and large developing countries, and gradually extended to work with more countries around the world through to better realize the complementary advantages and win-win cooperation.

Under the global crisis, for the western developed countries, to really make their own out of the crisis, in fact just rely on restrict imports to protect their country's economic development to achieve economic recovery and development, in order to get out of the economic crisis, achieve economic Renaissance, obviously, in the long run, these measures are only temporary relief from the plight of its economy, due to the economic growth of kinetic energy less than the fundamental problem for a long time, if can not fundamentally solve the inevitable will eventually fundamentally restricts the sustainable and healthy development of economy, so under the condition of the existing economic growth momentum is insufficient, Western countries need to fundamentally seek new economic growth drivers or new engines of economic development, so that the economic giant can set sail again, so as to open up more possibilities for human civilization and more sustainable development.

Obviously be able to activate the new engine of the world economy in today's world, is not to seek a zero-sum game between countries, on the contrary, in the face of the world of today, countries face increasingly strip has a global common challenges, how to seek better response, it is more need to strengthen cooperation between countries is more optimized, concentrated wisdom from country to country, and play the comparative advantage, through the complementary advantages to ride the waves in the face of these challenges, and finally leads to the other side of victory, successfully build a harmonious world complement each other.

This effectively means that the countries in the world today along with the development of economic globalization, the increasingly become a common fate of human destiny community, this makes a closer link between countries in the world today any country can feel more and more, under the age of economic globalization, any country in the world is not immune, so the world is increasingly becoming a community of the fate of a glorious all glory, broken. So any development and prosperity of a country, is not only rely on their own can do it, it need to rely on the overall

ISSN: 0010-8189 
prosperity and stability of the world economy to become the state of sustainable development, in the same way if the world economy is just a country or a few countries economic development and prosperity, and the vast majority of countries in the world economic development is relatively slow, in the long run will obviously fundamentally restricts the sustainable development of global economy, once the global economic development, so that once development and prosperity of individual countries or a few countries will obviously be dragged into this trap economic development dilemma Ultimately, it will also fundamentally restrict the economic development and prosperity of these countries. Therefore, as a western developed country, in order to truly realize the recovery and development of its own economy and thus get rid of the crisis fundamentally, it needs to strengthen the cooperation with other countries in the world, so as to truly provide a more lasting and strong driving force for its own economic development.

This shows that western developed countries should treat the economic development and prosperity of all countries in the world with a more open and inclusive attitude. The economic development and prosperity of more and more countries in the world actually means the arrival of the spring of the world economy. Because one is not spring, spring flowers really means, therefore the ancient silk road had brought along the country gradually to prosperity, Europe's new air route opened up, opens the market dominated by the western world, brings to the economic prosperity of the main developed countries in Europe, the former means the world economic boom spring or early spring the coming of The Times, so in the face of today's "after the era of globalization" need to promote and push more countries in the world can be more fair and more free to share the resources of the economic globalization, so that more countries in the world can achieve the development of higher quality, Only then can the world economy truly realize the flourishing scene of a hundred flowers blossoming, and all countries in the world truly walk out of the dilemma facing the world economy at present, so as to move towards a more prosperous world.

2.2 Methodology of historical research on the formation and development of the world market from "The Silk Road" to "One Belt And One Road"

\subsubsection{Literature research method}

In order to understand the development trend of the world market more clearly, we must seek from the longitudinal history, so as to understand and grasp the essential law of the world market movement more comprehensively and profoundly. Through literature research, therefore, from the development of world markets longitudinal come up to a comprehensive theory of the comb, based on the theory of overall description to explore development law of its formation, In this way, we can better find the way out of the predicament in the face of the sluggish world economic recovery in the present era.

\subsubsection{Exploratory research method}

To fully absorb and utilize the existing theoretical achievements of world market research, to develop new theoretical breakthroughs based on these theories, so as to continuously enrich and develop relevant theories and theories of world market.

\subsubsection{Information research methods}

To fully collect, process and sort out a large amount of information resources of existing relevant theoretical research results, so as to systematically and comprehensively explore the deep level rules of the formation and development of the world market.

\subsubsection{Scientific thinking method}

Comprehensive use of inductive deduction, analogical reasoning, abstract generalization, speculative imagination, analysis and synthesis of a series of existing world market theory materials for analysis and comprehensive research.

\subsubsection{System science method}

Comprehensive use of system theory, cybernetics, information theory and other comprehensive ways of thinking, from each stage to more comprehensive comparison of the world market theory. 


\section{Date Analysis}

From the opening of the ancient silk road to the formation of "One Belt And One Road", its entire development process actually reflects and conforms to the inevitable trend of historical development.

3.1 The Silk Road provided important conditions for the formation and development of the world market

we start from the development history of the ancient Silk Road to gradually explore the development track of this period of history. Along with the formation and development of the ancient Silk Road, the continuous development and expansion of commodity trade exchanges between countries along the silk Road gradually formed a commodity trade communication network spanning Asia, Europe and Africa, and gradually spread to the global scope, thus laying an important foundation for the formation and development of economic globalization. It is based on the analysis of Fig 1

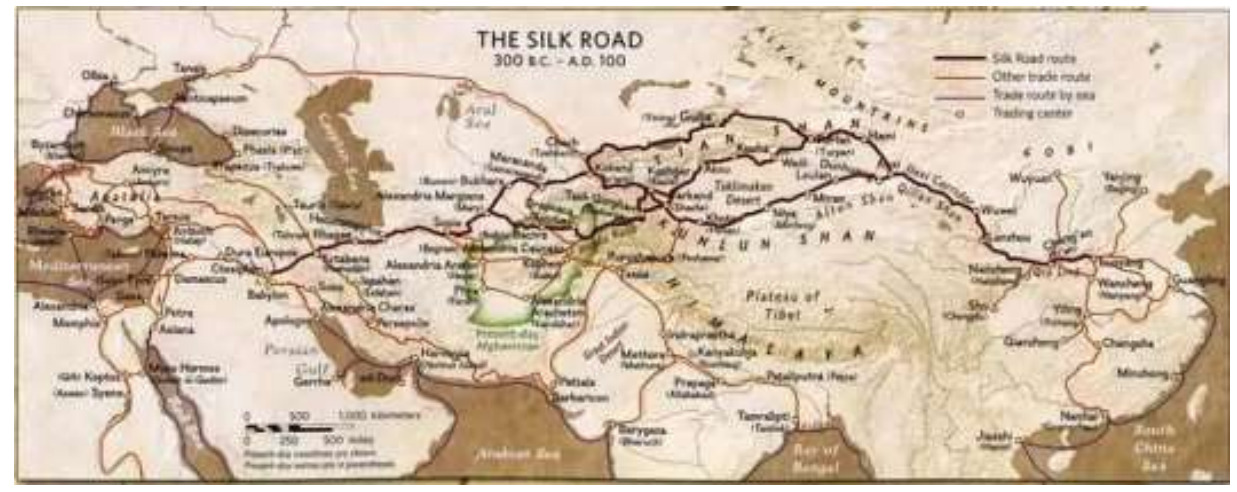

Fig 1: Trade routes in The Silk Road

As Peter-Frankopan says in the preface to The Silk Road: A New World History, "It was on this bridge connecting east and West that great city-states were built nearly 5,000 years ago: Harappa and Mohendzo·Darrow in the Indus Valley became wonders of the ancient world... Europe could not match it for thousands of years. Other massive centers of civilization, such as Babylon in Mesopotamia, Nineveh, Uruk and Akkad... The Baktrians on the Uhu river were very good at negotiation and trade. Their country became a market for all kinds of commodities, and the sources of supply were both remote and extensive... Standing here, you can open a new window on history, you will see a complex interwoven world; Continents interact with each other, what happens in the steppes of Central Asia can be felt in North Africa, what happens in Baghdad can be heard in Scandinavia, and new discoveries in the Americas will affect the prices of Chinese products, leading to a surge in demand for horses in northern India... This sprawling network was officially named by a famous German geographer and geologist named Ferdinand·von $\cdot$ Richthofen. Since then, the name Seidenstraßen has been named -- the Silk Road." [2] from Frankopan's discourse as a connection between east and west has fully illustrated important channel of the silk road trade exchanges, promote the region along the country's economic prosperity step by step, so as to promote the economic and trade along the scale expands unceasingly, along the state economic and trade exchanges between the increasingly frequent, deepening the relationship between each other, and any changes a country market will trade have important influence on the related countries, thus forming a increasingly close economic relationship.

\subsection{The formation and development of capitalist world market and its influence}

Apparently associated body the formation and development of the economy for the establishment of the world market is dominated by the west's laid the important foundation, through along the silk road connected to the communication between countries commodity exchanges as the link of the huge market network, for the world to build up good economic and trade exchanges between east and west market based environment, Combined with the analysis of Fig 1 and Fig 2, it can be seen that the new routes were opened up, the commercial routes were shifted, but the new trade routes opened, not fundamentally change based on the silk road between east and west of the economic and trade exchanges between the east and west, concrete system, In essence, it is only a further expansion and

ISSN: 0010-8189

(C) CONVERTER 2020

www.converter-magazine.info 
development of the east-West economic and trade network system established by the Silk Road.

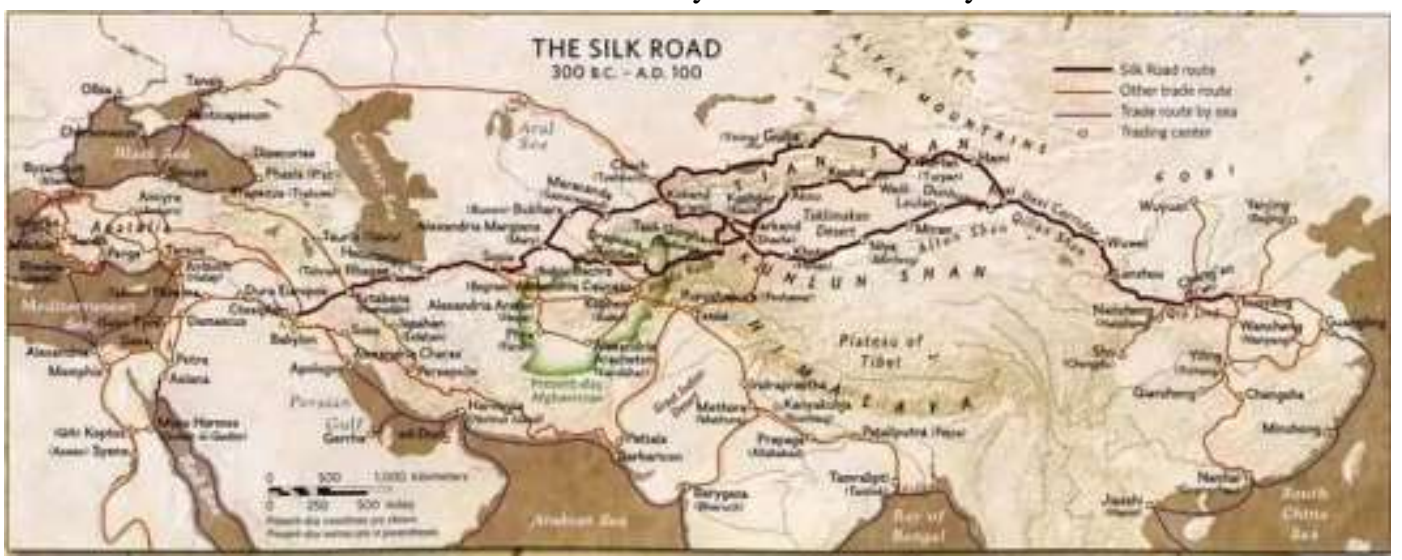

Fig 1: Trade routes in The Silk Road

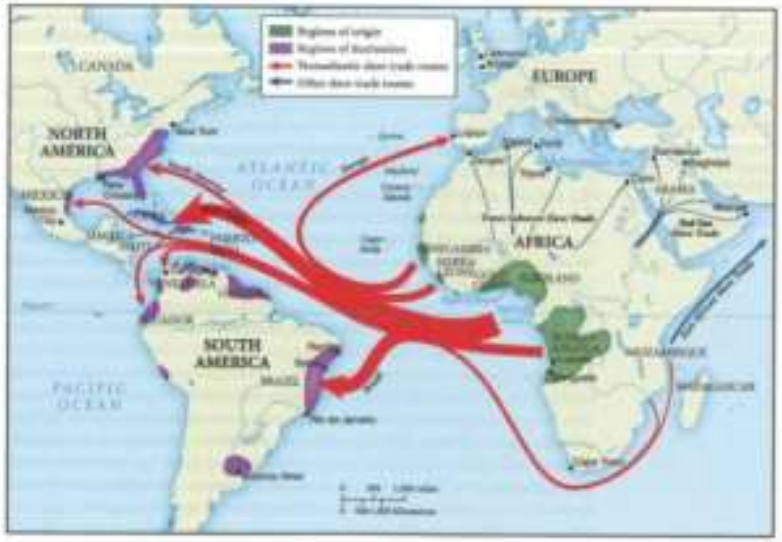

Fig 2: Trade routes in capitalist world markets

Therefore, in a sense, it can even be said that the establishment of such a basic economic and trade network laid by the Silk Road for the eastern and Western world has played an important role in promoting the establishment of a broader world market after the opening of new shipping routes. This shows that the Silk Road actually promoted the realization of the globalization of the consumer market in a sense. Of course with the new air route opened up, the transfer of trade routes, the silk road along the eastern country gradually decline, while the western countries after the new route opened up, with its favorable conditions to rise gradually, and continuously explore new territory in the world, as well as the original Asia market and African market into its colonial system, increasingly from belongs to the west to east, so as to gradually establish a market system dominated by the western world.

In a certain period of time, this system has promoted the expansion and development of the world market to a certain extent, and further promoted the globalization of production on the basis of promoting the globalization of consumption, thus injecting strong impetus into the economic globalization. As Marx pointed out in Manifesto of the Communist Party "The bourgeoisie, by opening up the world market, has made the production and consumption of all countries worldwide." [3] "The bourgeoisie, in its less than one hundred years of class rule, has produced more and more productive forces than all previous generations have produced in their entirety." [4] But in the long run, because under this system, it is difficult to provide a relatively fair market environment for the development of eastern countries, in the long run, the economic gap between eastern and Western countries will continue to widen, the gap between the rich and the poor will widen day by day, which will inevitably ultimately restrict the sustainable and healthy development of the global economy.

3.3 The adjustment and change that contemporary world market development

ISSN: 0010-8189 
Therefore, after the long-term development of this system, its negative benefits have been fully manifested under the global economic difficulties since the global economic crisis caused by the American subprime mortgage crisis in 2008. Under the crisis, in a strong economic position in the system for a long time in the western world economy after suffering defeat, began to compress overseas economic and trade scale, the main focus on trying to boost their economies, the recovery and development of the eastern countries under this system itself is weak for a long time, slow economic development. This crisis is nothing less than a further blow to the economy, which has caused the world economy to suffer an unprecedented huge cold wave, and the world economy has entered the winter of extremely difficult economic recovery.

So if we want to fundamentally reverse the global economy at present, will need to start more conducive to promote economic recovery and development of kinetic energy, let more countries in the world can become great helmsman, boosting the world economy in today's world each country only better forward hand in hand, can under the crisis and the huge waves, was able to swim to overcome the common human face waves and trial, to open up the human more beautiful of the bright future of sustainable development. This means that we need to make adjustments and changes to the existing economic system so as to truly open up new prospects for global economic development. The world today is in a big adjustment, the era of change, the challenges faced by countries around the world in the development of economy and risk in constant increase, the challenge and risk is not only a kind of local, regional, and tend to be large, even global, and is therefore not just rely on one or a few countries will be able to deal with, often need to jointly cope with the world each country combination to solve it, this means that it needs to let more countries really play their respective comparative advantage in the era of economic globalization, more and more developed countries, In order to better deal with the current era under the various complex challenges and risks.

This is why in the world's financial crisis, in the original market dominated by the western world, why has not been out of the crisis, under the economy hit the world not only failed to strengthen cooperation and well better play to their countries' comparative advantage, to develop or engage in trade protectionism on a large scale, is many countries to protect their own economy, strong against other countries goods, this will no doubt further aggravate the deterioration of the world economy, economic crisis actually brought the world economy, takes the world unite to better and faster healing wounds, makes the economy to faster recovery and development. Of course still need time to recovery of world economy, so the traditional market is dominated by the western world if it is an important engine to promote the development of world economy, if you want to restart after the economic crisis, will take the time to actively recovery can be completed as soon as possible, however, for the moment the economic engine recovery situation is not optimistic, as Peter-Frankopan in The Silk Roads: A New History of The World pointed out that "in western countries are at a crossroads, if their time is not over yet... President Barack Obama... Point out his views on the future: 'Our country is in transition. The world changes before our eyes...'... The Mod has come to the same conclusion." [5] which means that the European and American developed countries to continue to maintain its position in the world market, also need to adjust and change through the depth can better adapt to today's era of globalization, and the adjustment and change obviously need to strengthen cooperation with the rest of the world to achieve better, so if you can't really world to unite and play their respective comparative advantage to enhance cooperation, apparently only makes the engine restart time continue to delay.

Therefore, for the world economy to really get out of this crisis, on the one hand, all countries in the world need to join hands to build a world community with a Shared future to deal with global challenges through sincere cooperation. In fact, this depends on the establishment of a fairer and more reasonable international economic new order. The engine, on the other hand, the world needs to fully restore and recovery time, this does not mean that we want to slow down the pace of world economic development, the human world to better continue, obviously depend on the continuously development of the world to realize, however, the development of the world today is to achieve not only is the growth of the world economy, and it requires a more balanced, more harmonious world, higher quality, more sustainable development. This means that under the old engine of the world economy, we must start a new engine of world economic development, which will enable more countries to make better use of their comparative advantages, so that the world economy can achieve sustained and healthy development driven by two

ISSN: 0010-8189 
engines or even multiple engines.

\section{Conclusion}

In this context, the Chinese government to keep up with the development trend of The Times, The time to put forward the "area" all the way.

\section{1 "One Belt And One Road" follows the historical trend of the development of the world market}

Based on the analysis of Fig 1, Fig 2 and Fig 3, it can be seen that with the development of "area", in fact on the basis of the original in the world market, restart and revive the ancient countries along the silk road, and constantly expand the range of countries, and it contains radiation.

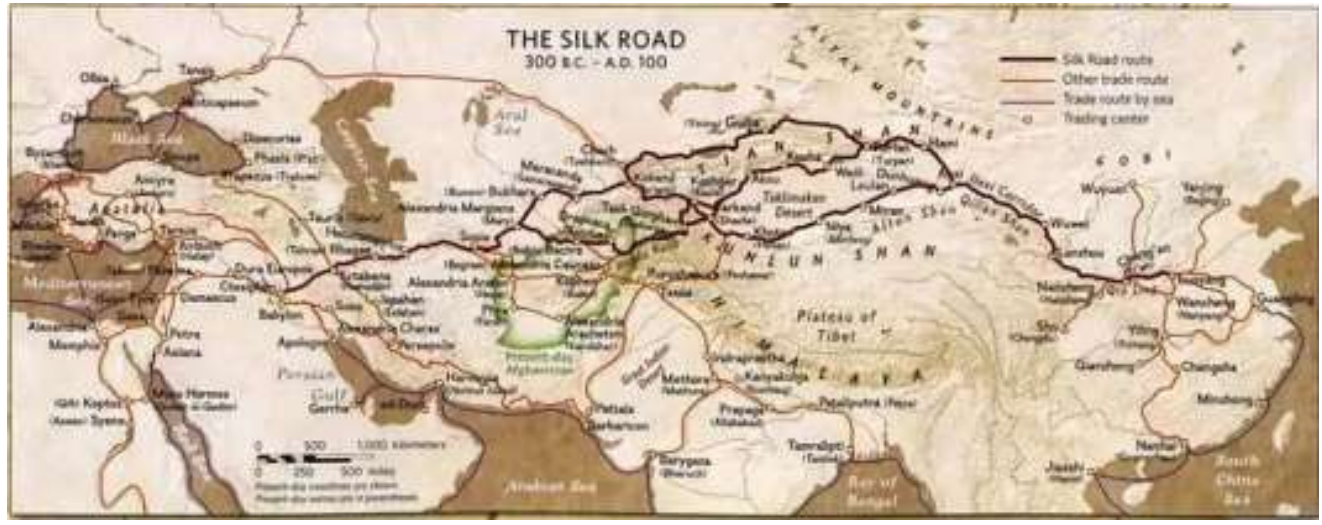

Fig 1: Trade routes in The Silk Road

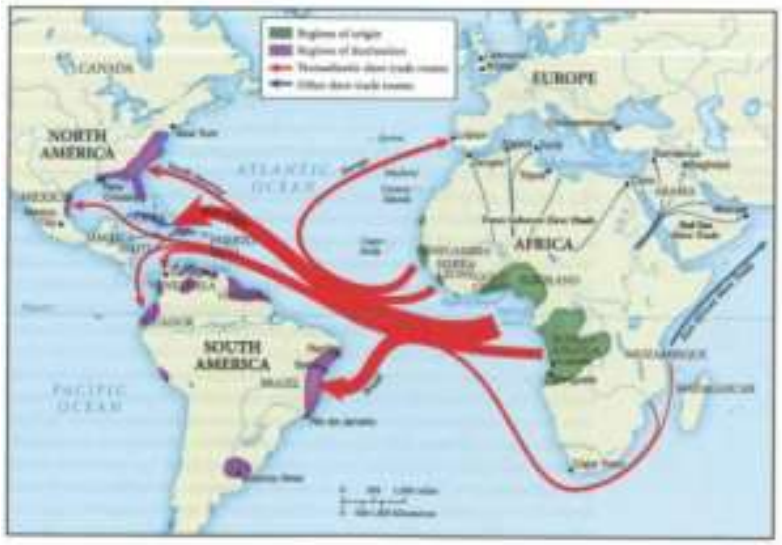

Fig 2: Trade routes in capitalist world markets

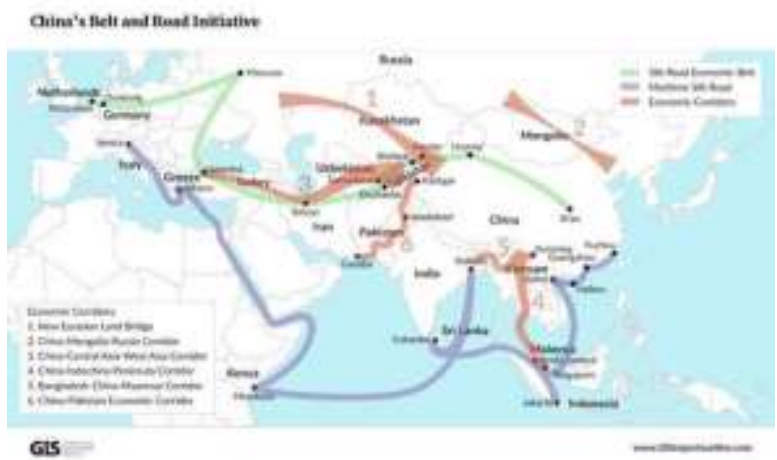

Fig 3: Trade routes in One Belt And One Road 
Today, with a more active and open attitude, we welcome more countries to join the One Belt And One Road and work together to build a community with a Shared future for mankind, so as to build a more harmonious and prosperous world. The belt and Road initiative has provided a platform for development, especially for those countries along the belt and Road that have been in a weak position in the traditional world market for a long time. Of course, for those countries that once had a dominant position in the traditional world market, if they are willing to join in the "One Belt And One Road" sincerely to seek common development, they can also better promote the development of their own countries through the mutual cooperation between countries along the "One Belt And One Road".

By promoting the development of more countries, China will provide a more durable driving force for world economic development. It means that the "One Belt And One Road", as a comprehensive, open and inclusive system, provides a big platform for sound development of the world economy. Therefore, as Peter-Frankopan pointed out in his evaluation of China's "One Belt And One Road" construction, "the 'One Belt And One Road' plan proposed in 2013 and the huge investment China has made in this plan fully show that China is thinking about the future. In the rest of the world, setbacks and hardships, challenges and problems seem to be the birth pangs of a new world... The communication networks on the roof of Asia are quietly weaving together, or rather re-establishing themselves. The Silk Road is being revived."[6] so although this scheme launched by China, but not by the achievements of China's exclusive, but universal benefits to the world, it will be beneficial to promote the common economic development of countries along the Belt and Road as well as all countries in the world, gradually build up human destiny community, promote global economic recovery, for global economic governance system of China's thinking about the solution.

4.2 The influence and function of "One Belt And One Road" on promoting the development of world market

Therefore, "One Belt And One Road" is not just a road to world economic prosperity. It is a road of hope, with world economic cooperation and exchanges at its core, to promote all-round political and cultural prosperity and development of the world. This is a new engine that China is seeking to promote world economic recovery and sustained and sound development. We are committed to building a better future for human development and a more prosperous, democratic, civilized, harmonious and beautiful world. Due to the peace and development remain the themes of our era, the center of the world is still committed to strive for a peaceful environment to work continuously promote the national economy development, peace and development is a common dream and the world's largest consensus, "One Belt And One Road" is to adapt to the mainstream of development trend in this era and the formation and development. So as Peter-Frankopan puts it, "Now is a good time to strengthen economic ties, roads, trade and money, but also to build a silk Road Economic Belt, in other words, a new Silk Road." [7] this shows that the time has come for the "One Belt And One Road" construction. Therefore, we should actively follow this development trend, take the "One Belt And One Road" construction and development as a link, and promote the optimization of cooperation among countries in the world to further boost the great development and prosperity of the global economy. "Area" construction itself, of course, is a need to according to the world as well as the time development and the process of continuous development and perfection, so we should always keep in the construction and development of the open inclusive, eclectic, the attitude of the reform and innovation to constantly adjust and perfect, to push economic globalization towards more healthy and orderly development, and create a better tomorrow for human society.

\section{References}

[1] Marx, "Engels compilation and Translation Bureau of the CPC Central Committee," Collected Works of Marx and Engels, People's Publishing House, vol. 1, pp. 501, 2009.

[2] Peter-Frankopan, "The Silk Roads: A New History of The World," Zhejiang University Press, pp. 3-4, 2016.

[3] Marx, "Engels compilation and Translation Bureau of the CPC Central Committee," Collected Works of Marx and Engels, People's Publishing House, vol. 2, pp. 35, 2009. 
[4] Marx, "Engels compilation and Translation Bureau of the CPC Central Committee," Collected Works of Marx and Engels, People's Publishing House, vol. 2, pp. 36, 2009.

[5] Peter·Frankopan, "The Silk Roads: A New History of The World," Zhejiang University Press, pp. 445, 2016.

[6] Peter-Frankopan, "The Silk Roads: A New History of The World," Zhejiang University Press, pp. 447, 2016.

[7] Peter-Frankopan, "The Silk Roads: A New History of The World,” Zhejiang University Press, pp. 446, 2016. 